\title{
A New Family of Small (4kDa) Neurotoxins from the Venoms of Spiders of the Genus Phoneutria
}

\author{
A.D. Lúcio ${ }^{\mathrm{a}, \mathrm{e}}$, F.V. Campos ${ }^{\mathrm{b}, \mathrm{f}}$, M. Richardson ${ }^{\mathrm{c}}$, M.N. Cordeiro ${ }^{\mathrm{c}}$, M.S.C. Mazzonia ${ }^{\mathrm{a}}$, M.E. de Lima ${ }^{\mathrm{b}}$, \\ A.M.C. Pimenta ${ }^{\mathrm{b}}$, M.P. Bemquerer ${ }^{\mathrm{b}, \mathrm{g}}$, S.G. Figueiredo ${ }^{\mathrm{d}}$, P.C. Gomes ${ }^{\mathrm{c}}$ and P.S.L. Beirão ${ }^{\mathrm{b}, *}$
}

\begin{abstract}
${ }^{a}$ Dept. of Physics; Instituto de Ciências Exatas; UFMG; Av. Antonio Carlos 6627; 31270-901 Belo Horizonte; MG; Brazil; ${ }^{b}$ Dept. of Biochemistry and Immunology; Instituto de Ciências Biológicas; UFMG; Av. Antonio Carlos 6627; 31270-901 Belo Horizonte; MG; Brazil; ${ }^{c}$ Centro de Pesquisa e Desenvolvimento Prof. Carlos R. Diniz; Fundação Ezequiel Dias; Rua Conde Pereira Carneiro 80; 30510-010 Belo Horizonte; MG; Brazil; ${ }^{d}$ Dept. of Physiological Sciences; Centro Biomédico; UFES; Av. Marechal Campos 1468; 29040-090 Vitória; ES; Brazil; ${ }^{e}$ Present address: Dept. of Exact Sciences; UFLA; CP 3037; CEP 37200-000; Lavras; MG; Brazil; ${ }^{f}$ Present address: University of Chicago; 929 East 57th Street, Chicago IL, 60637, USA; ${ }^{g}$ Present address: Embrapa Recursos Genéticos e Biotecnologia, Parque Estação Biológica - PqEB - Av. W5 Norte, 70770-900, Brasília; DF; Brazil
\end{abstract}

\begin{abstract}
A family of 4kDa neurotoxic peptides was purified from venoms of Phoneutria spiders. All have six cysteine residues, and low similarity with other neurotoxins. Three toxins caused moderate inhibition of L-type $\mathrm{Ca}^{2+}$ channels. The structure of toxin PRTx27C3 was modeled and compared with toxin ADO1. The importance of four residues is suggested.
\end{abstract}

Keywords: Spider toxin, neurotoxin, Phoneutria, amino acid sequences, L-type $\mathrm{Ca}^{2+}$ channels, molecular modeling.

\section{INTRODUCTION}

One of the most intriguing features of peptide toxins is that many of them have similar actions despite having dissimilar sequences and folds, whereas others have diverse effects even when having similar sequences or folds [1]. This poses the interesting question of which are the structural determinants of specific actions and the key amino acid residues (and their respective positions) that are crucial for the binding of a toxin to its target, such as an ion channel. One of the strategies to reveal the structural determinants of a certain action is to compare naturally occurring toxins with different structures but with similar effects. This comparison may provide clues as to the major characteristics required for a specific mode of action.

The venom of the very aggressive South American solitary spider Phoneutria nigriventer (Keys.) has been extensively studied and contains a wealth of biologically active peptides and proteins. Many of them act on ion channels or membrane receptors of insects and mammals, and may serve as models for the development of new biologically active compounds with potential use in medicine or agriculture [24]. Excitatory symptoms such as salivation, lachrymation, priapism, convulsions, followed by flaccid or spastic paralysis and death occur following icv injection in mice [5]. The venom of Phoneutria nigriventer was fractionated into four groups of peptides with neurotoxic activity (denominated PhTx1, PhTx2, PhTx3 and PhTx4), that have different primary structures and pharmacological properties [6-10], revealing it as a rich source of bioactive peptides. PhTx1 was

*Address correspondence to this author at the Dept. of Biochemistry and Immunology; Instituto de Ciências Biológicas; UFMG; Av. Antonio Carlos 6627; 31270-901 Belo Horizonte; MG; Brazil; Tel: 55-31-3409-2663; Fax: 55-31-3409-2614; E-mail: pslb@ufmg.br shown recently to have a voltage dependent inhibitory activity on $\mathrm{Na}^{+}$channels [11]. Fraction PhTx2 is responsible for the venom's prevailing excitatory symptoms by inhibiting $\mathrm{Na}^{+}$channel inactivation. It is composed of 9 peptides, 8 of which with high similarity. Toxins PnTx2-5 and PnTx2-6 have been extensively studied and were shown to inhibit $\mathrm{Na}^{+}$ channel inactivation $[12,13]$ Fraction PhTx 3 was shown to be a complex mixture of at least six different toxins with diverse pharmacological properties [9]. Most of these had their primary activity characterized. PnTx3-1, was shown to inhibit the A-type $\mathrm{K}^{+}$current that is associated with $\mathrm{Ca}^{2+}$ oscillation and pacemaker activity [14]. PnTx3-3 is a $\mathrm{Ca}^{2+}$ channel inhibitor, with higher affinity to P/Q- and R-type channels [15-17], PnTx3-4, also referred to as $\omega$-phonetoxin IIA, inhibits $\mathrm{N}$ and P/Q-type $\mathrm{Ca}^{2+}$ channels with high affinity, and L-type $\mathrm{Ca}^{2+}$ channels with lower affinity $[18,19]$. PnTx3-6 inhibits $\mathrm{Ca}^{2+}$ channels with higher affinity for Nand R-type channels [20]. PnTx3-2 was shown to inhibit Ltype $\mathrm{Ca}^{2+}$ channels, but possible activities on other types of $\mathrm{Ca}^{2+}$ channels have not been investigated yet [21], PhTx4 is active on insects and has much weaker toxic effects on mice [10]. All these toxins are peptides with molecular masses of 3.5 to $9 \mathrm{kDa}$. Most of these toxins had their sequences determined chemically, and subsequently confirmed (in a few cases with small corrections) by the analysis of clones from cDNA libraries constructed using the venom gland of the spider [13, 14, 21-24].

Recently it has been demonstrated the presence of a highly complex pool of smaller (up to $2 \mathrm{kDa}$ ) peptides that provoke contractions in the smooth muscle of guinea pig ileum. The amino acid sequences of 15 isoforms were determined by tandem mass spectrometry [25]. All of these molecules, which are structurally related to the tachykinin family of neuro-hormone peptides, possessed $\mathrm{N}$-terminal 
pyroglutamate residues and exhibited evidence of other posttranslational modifications such as proteolysis and $\mathrm{C}$ terminal amidation.

In the present work we now describe another new family of small $(4 \mathrm{kDa})$ toxins obtained from Phoneutria nigriventer and from the venoms of the two related species of spiders Phoneutria reidyi and Phoneutria keyserlingi. These small proteins caused spastic paralysis and death when injected icv in mice, and all but one have inhibitory effects on L-type currents of GH3 cells. Their primary structures show that they are unrelated to previously described toxins. We propose a molecular model for the most active of these toxins, PRTx27C3, and based on comparison with the sequence and structure of other toxins, the importance of the amino acid residues R6, K14, F26 and K18 is speculated.

\section{MATERIALS AND METHODS}

\section{Venoms}

Male and female specimens of the spiders Phoneutria nigriventer (Keys.) and Phoneutria keyserlingi were collected in the region of Santa Barbara and Mariana, respectively, both in the state of Minas Gerais (Brazil), and kept in the arachnidarium of the Fundação Ezequiel Dias (Belo Horizonte, Brazil). Venom from the live adult spiders was obtained by electrical stimulation of the fangs (5-12 $\mu \mathrm{l} / \mathrm{spider}, 160 \mathrm{mg} / \mathrm{ml}$ ), transferred to siliconized glass tubes in ice, diluted with the same volume of distilled water and centrifuged at $4000 \mathrm{x} \mathrm{g}$ to remove insoluble materials and cellular debris. The supernatant was lyophilized and stored at $-18{ }^{\circ} \mathrm{C}$. The venom of the spider Phoneutria reidyi, which was collected from specimens captured in the Amazon region near the hydro-electric reservoirs at Tucurui (Pará), Samuel (Roraima) and Balbina (Amazonas), was a generous gift from the Butantan Institute (São Paulo, Brazil).

\section{Purification of Venom Proteins}

The venoms of all three species were processed in the same manner. Aliquots of $25-30 \mathrm{mg}$ of lyophilized venom were dissolved in $2 \mathrm{ml}$ of aqueous $0.1 \%$ TFA and centrifuged at $4000 \times \mathrm{g}$ for $10 \mathrm{~min}$ to remove insoluble materials. The brownish yellow supernatant was applied to a preparative reversed-phase column $(2.2 \mathrm{x} 25 \mathrm{~cm}$ Vydac $\mathrm{C} 4$ $214 \mathrm{TP} 1022$ ) equilibrated with $0.1 \% \mathrm{TFA}$ in water (solvent A). Solvent B was $100 \%$ acetonitrile containing $0.1 \%$ TFA. The column was eluted at a flow rate of $5 \mathrm{ml} / \mathrm{min}$ with the following gradient system: 0 to $20 \mathrm{~min}, 100 \% \mathrm{~A}$; 20 to 30 min, $0-20 \% \mathrm{~B} ; 30$ to $110 \mathrm{~min} ; 20-40 \% \mathrm{~B} ; 110$ to $130 \mathrm{~min}, 40-$ $50 \% \mathrm{~B} ; 130$ to $150 \mathrm{~min}, 50-70 \% \mathrm{~B}$. The presence of peptides or proteins in the eluate was detected by measuring the UV absorption at $214 \mathrm{~nm}$. Fractions containing peptides or proteins were collected manually and lyophilized.

The lyophilized fractions obtained from the preparative reversed-phase HPLC were then dissolved in $2 \mathrm{ml}$ of $10 \mathrm{mM}$ sodium phosphate buffer $\mathrm{pH}$ 6.1, and subjected to ionexchange FPLC on a column $(6.4 \mathrm{~mm} \times 30 \mathrm{~mm})$ of Resource $^{\mathrm{TM}} \mathrm{S}$ (Amersham Pharmacia Biotech) equilibrated in the same buffer. After application of the sample, the column was initially washed with the starting buffer for $10 \mathrm{~min}$ and then eluted with a gradient of $0-0.5 \mathrm{M} \mathrm{NaCl}$ in the same buffer at a flow rate of $1 \mathrm{ml} / \mathrm{min}$ over a period of $45 \mathrm{~min}$. In one experiment the material obtained from the reversedphase step was fractionated on an anion exchange HPLC column $(4.1 \mathrm{~mm} \times 30 \mathrm{~cm})$ of Synchropak AX-300 using a linear gradient of $0-0.5 \mathrm{M} \mathrm{NaCl}$ in $10 \mathrm{mM}$ Tris- $\mathrm{HCl}$ buffer $\mathrm{pH} 8.6$ at a flow rate of $1 \mathrm{ml} / \mathrm{min}$. The fractions collected were desalted and further purified by reversed-phase HPLC on an analytical column (4.6 mm x $25 \mathrm{~cm}$ Vydac C18 218 TP54) using a linear gradient of $0-40 \%$ acetonitrile in $0.1 \%(\mathrm{v} / \mathrm{v})$ TFA over $60 \mathrm{~min}$. The homogeneity of all fractions obtained was examined by masss spectrometry and propionic acid/urea PAGE using the method described by Chettibi and Lawrence [26]. The gel mixture contained 22.5 $\mathrm{g}$ of acrylamide monomer, $0.8 \mathrm{~g}$ of bis-acrylamide, $36 \mathrm{~g}$ of urea and $2 \mathrm{ml}$ of propionic acid made up to $100 \mathrm{ml}$ (final volume) with distilled water. To $60 \mathrm{ml}$ of this solution was added $400 \mu \mathrm{l}$ of $10 \%(\mathrm{w} / \mathrm{v})$ ammonium persulphate solution and $50 \mu \mathrm{l}$ of TEMED. Gels were run with $2 \%$ acetic acid in both anode and cathode compartments. Samples were prepared by addition of an equal volume of $30 \%$ sucrose solution containing neutral red marker dye. After running gels were stained with $0.1 \%$ Coomassie blue in methanol/water/acetic acid (50/50/7), and destained in methanol/acetic acid/water (5/7/100).

\section{Mass Spectrometry Analyses}

ES-Q-TOF mass spectrometry analyses were carried out using a Q-TOF Micro ${ }^{\text {TM }}$ (Micromass, UK) equipped with an electrospray ionization source operated in the positive mode. Capillary voltage was $3000 \mathrm{~V}$ and sample cone voltages were 40-60 V. Mass spectrometer calibrations were made by using sodium iodide with cesium iodide in 2000 Da range. Samples diluted in 50\% acetonitrile/ $0.1 \%$ TFA were introduced by using a syringe pump with flow rates of 5-10 $\mu \mathrm{l} / \mathrm{min}$. The spectrum used was the result from 20 scans $(2.4$ s) combined. Original data $(\mathrm{m} / \mathrm{z})$ were treated (base line subtraction, smoothing and centering) and transformed into a mass (Da) spectrum. Collision induced dissociation (MS/MS) was carried out using argon and collision energies in the range $30-45 \mathrm{~V}$. Data analyses were carried out with MassLynx ${ }^{\circledR} 3.5$ software.

\section{Bioassays}

The toxicity of each fraction was assayed by icv injection in albino mice (18-22 g). The animal assays were kept to a minimum and were carried out in accordance with ethical procedures of the Fundação Ezequiel Dias. The lyophilized samples were dissolved in $0.15 \mathrm{M}$ saline, containing 0.25 $\mathrm{mg} / \mathrm{ml}$ of BSA for icv injection of $5 \mu 1$ samples, as described by Rezende et al. [7]. The appearance of neurotoxic symptoms (excitation, salivation, lachrymation, priaprism, spastic or flaccid paralysis, scratching, tail elevation) or the death of animals was observed after injection. Control animals received physiological saline alone. All assays were carried out in duplicates.

\section{S-Reduction and Alkylation}

The proteins (20-200 nmol) were S-reduced and alkylated with 4-vinyl pyridine essentially as described by Henschen [27]. The material was dissolved in $1 \mathrm{ml}$ of $6 \mathrm{M}$ gua- 
nidine-HCL in $0.1 \mathrm{M}$ tris-HCL, $\mathrm{pH}$ 8.6, To this solution 30 $\mu \mathrm{l}$ of 2-mercaptoethanol was added under nitrogen, and the sample incubated at $50{ }^{\circ} \mathrm{C}$ for $4 \mathrm{~h}$. After this, $40 \mu \mathrm{l}$ of 4 -vinyl pyridine was added and the samples were incubated at $37{ }^{\circ} \mathrm{C}$ for a further $2 \mathrm{~h}$. The reduced and alkylated proteins were recovered by desalting on a column $(4.6 \mathrm{~mm} \times 25 \mathrm{~cm})$ of Vydac C4 (214TP54), by using a gradient of 0 to $70 \%$ acetonitrile in $0.1 \%$ trifluoroacetic acid over $70 \mathrm{~min}$ at a flow rate of $1 \mathrm{ml} / \mathrm{min}$. The collected proteins were lyophilized.

\section{Determination of Amino Acid Sequences}

Samples (4-10 nmol) of the S-pyridyl-ethylated proteins were dissolved in $1 \mathrm{ml}$ of $0.1 \mathrm{M}$ ammonium bicarbonate $\mathrm{pH}$ 7.9 and digested with trypsin for $3.5 \mathrm{~h}$ using $2 \%(\mathrm{w} / \mathrm{w})$ enzyme/substrate. After lyophilisation the peptides produced were separated by reversed-phase HPLC on a column (4.6 $\mathrm{mm} \times 25 \mathrm{~cm}$ ) of Vydac C18 (small pore, 201SP54) by using an extended gradient of 0 to $50 \%$ acetonitrile in $0.1 \%$ trifluoroacetic acid for $180 \mathrm{~min}$ at a flow rate of $1 \mathrm{ml} / \mathrm{min}$.

The amino acid sequences of the S-pyridyl-ethylated intact proteins $(2-10 \mathrm{nmol})$ and the peptides derived from them by the enzymatic digestion were determined by Edman degradation using a Shimadzu PPSQ-21A automated protein sequencer.

\section{Sequence Comparisons}

The amino acid sequence of the various proteins were compared with the sequences of other related proteins in the SWISS-PROT/ TREMBL data bases using the FASTA 3 and BLAST programs.

\section{Molecular Modeling}

A model for toxin PRTx27C3 was built by taking the toxin $\mathrm{ADO} 1$ as a reference, whose residues were replaced one by one according to the primary structure of toxin PRTx27C3. The resulting structure was used as an initial configuration for the molecular dynamics simulation.

Molecular dynamics simulations were carried out with the GROMACS package [28], using the force field Gromos 96 [29]. The toxin was solvated by 1054 SPC water molecules [30] in a cubic box with periodic boundary conditions. The temperature was set to $300{ }^{\circ} \mathrm{K}$ by means of the Berendsen scheme [31] of coupling to an external bath with coupling constant of 0.1 ps. A constant pressure of 1 bar was applied also by means of the Berendsen algorithm [31]. Before the actual simulation, a steepest descend method was employed to remove close contacts followed by a 400 ps position restrained molecular dynamics to equilibrate the water molecules around the peptide, which was kept fixed. Finally, the actual simulation was performed for $5 \mathrm{~ns}$ with a time step of $1 \mathrm{fs}$.

\section{Protein Nomenclature}

Each protein / peptide purified and studied during this work is described by a code. For example the species of Phoneutria from which it originated is indicated by $\mathrm{PN}=$ Phoneutria nigriventer; $\mathrm{PR}=$ Phoneutria reidyi, or $\mathrm{PK}=$ Phoneutria keyserlingi. The first number indicates the number of the peak eluted from the preparative reversed-phase
HPLC on Vydac C4 that contained the protein. The following letter $\mathrm{C}$ indicates that the second step was cationic exchange FPLC (Resource $\mathrm{S}$, pH 6.1). The subsequent number indicates the peak number during the second step.

\section{Electrophysiology}

GH3 cells were maintained in DMEM (Sigma Chemical Co., MO, USA) supplemented with Fetal Bovine Serum (Cultilab, Campinas, Brazil) 10\%, penicillin/streptomycin 1\% (Sigma Chemical Co., MO, USA) and incubated at 37 ${ }^{\circ} \mathrm{C}, \mathrm{CO}_{2} 5 \%$. The cells were detached with a trypsin/EDTA solution and plated in Petri dishes for electrophysiological measurements. Ionic currents were recorded from GH3 cells by using the whole cell patch clamp technique. The data were acquired either with a HEKA/EPC9 amplifier controlled by Pulse 8.11 software (HEKA Elektronik Gnbh, Lambrecht, Germany), sampled at $10 \mathrm{kHz}$ and filtered 3.33 $\mathrm{kHz}$ or with an Axopatch 200B amplifier controlled by Pclamp6 software (Axon Instruments, Union City, USA), sampled at $10 \mathrm{kHz}$ and filtered at $5 \mathrm{kHz}$. The voltage protocol used to record the currents was: from a holding potential of $-80 \mathrm{mV}$ were applied $100 \mathrm{~ms}$ pulses from $-100 \mathrm{mV}$ to 50 $\mathrm{mV}$ (10 $\mathrm{mV}$ increments). To analyze the current as a function of the time, the test pulse was set at $0 \mathrm{mV}$, where the maximal currents were observed (not shown). The protocol was repeated each $5 \mathrm{~s}$. Patch pipettes were pulled from soft glass capillaries with a tip resistance of 2-4 M 2 . The cells were sealed in a bath solution containing (in $\mathrm{mM}$ ): $\mathrm{NaCl} 130$, $\mathrm{KCl} 5, \mathrm{CaCl}_{2} 2, \mathrm{MgCl}_{2}$ 1, HEPES 10, Glucose 10, pH 7.4 with $\mathrm{NaOH}$. The currents were recorded under continuous perfusion of a control solution containing (in $\mathrm{mM}$ ): $\mathrm{NaCl}$ $100, \mathrm{BaCl}_{2} 25$, HEPES 10, Glucose $10, \mathrm{KCl} 5$, Tetrodotoxin 0.0003 , pH 7.4 with $\mathrm{NaOH}$. $\mathrm{Ba}^{2+}$ was substituted for $\mathrm{Ca}^{2+}$ as the charge carrier because it is conducted better and prevents the $\mathrm{Ca}^{2+}$-dependent inactivation, thus facilitating the measurement of the currents. The pipettes were filled with a solution containing (in $\mathrm{mM}$ ): $\mathrm{CsCl} 140$, EGTA 5, HEPES 10, ATP-Mg 4, pH 7.2 with $\mathrm{CsOH}$. The toxins were diluted to final concentrations of $200 \mathrm{nM}$ or $1 \mu \mathrm{M}$ in the control solution containing cytochrome $\mathrm{C} 4 \mu \mathrm{M}$ to prevent adsorption [17]. Data were analyzed with PulseFit 8.11 software (HEKA Elektronik Gnbh, Lambrecht, Germany), Clampfit (Axon Instruments, Union City, USA) and SigmaPlot 5 (Jandel Inc., USA), being presented as mean \pm SEM unless stated otherwise.

\section{RESULTS AND DISCUSSION}

The proteins described in this study were partially purified from the majority of the other venom components by subjecting the crude venoms of Phoneutria nigriventer, Phoneutria reidyi and Phoneutria keyserlingi to an initial step of reversed-phase HPLC on preparative columns of Vydac C4, by using extended gradients of acetonitrile in aqueous $0.1 \%$ TFA. The peaks collected at concentrations of $36-38 \%$ acetonitrile were numbered as PN26, PN27, PR27 and PK32, as shown in Fig. (1). After lyophilization, the contents of each fraction were examined by propionic acid/urea PAGE and by Q-TOF mass spectroscopy, which revealed that the major components in each fraction had a mass of approximately 4 $\mathrm{kDa}$, but were contaminated with other larger proteins. 


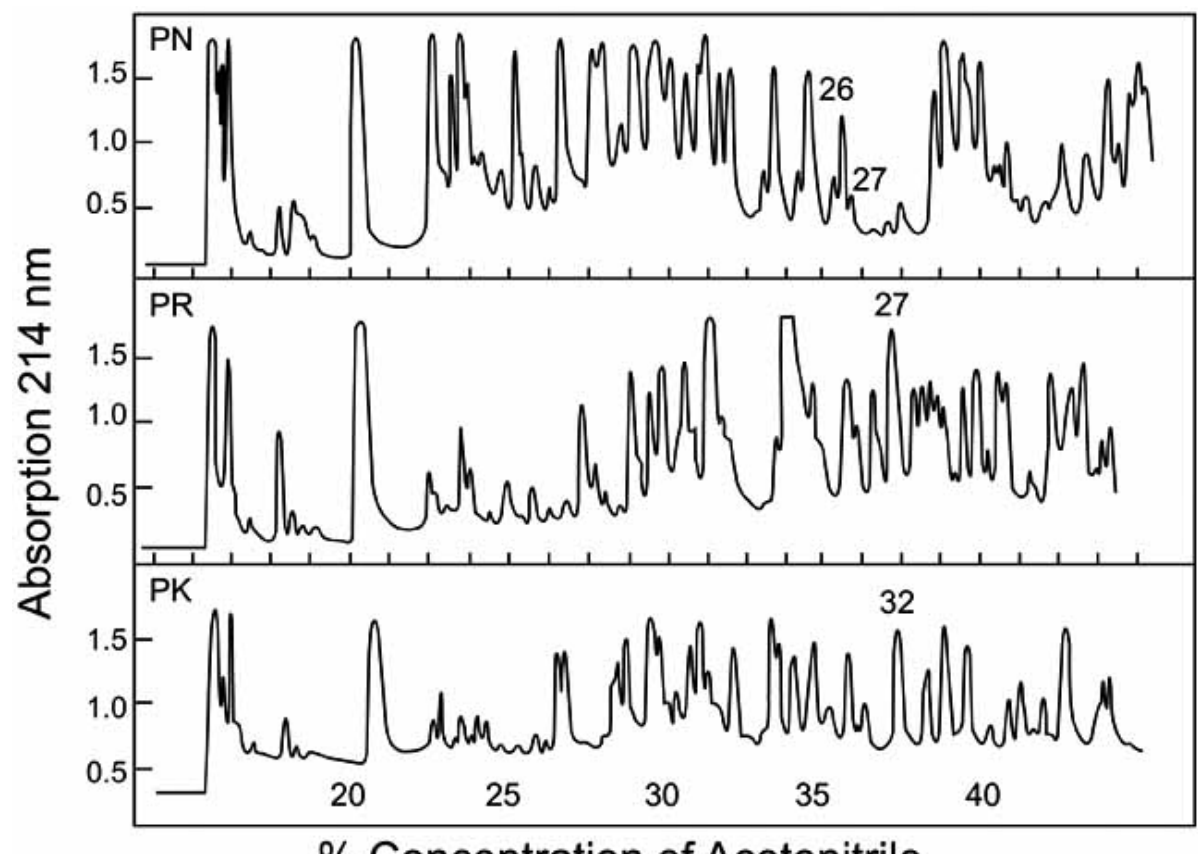

$\%$ Concentration of Acetonitrile

Figure 1. Profiles of the reversed-phase HPLC chromatograpy. Comparison of the preparative reversed-phase HPLC (Vydac C4) profiles obtained for the crude venoms of PN, Phoneutria nigriventer; PR, Phoneutria reidyi and PK, Phoneutria keyserlingi. The amount of protein injected onto the column was $30 \mathrm{mg}$ for PN and PR and $15 \mathrm{mg}$ in the case of PK. The presence of peptides or proteins in the eluate was detected by measuring the UV absorption at $214 \mathrm{~nm}$. The void volume was $55 \mathrm{ml}$. All other experimental details are given in the text. The arrows indicate the peaks which were collected and further purified by ion-exchange FPLC.

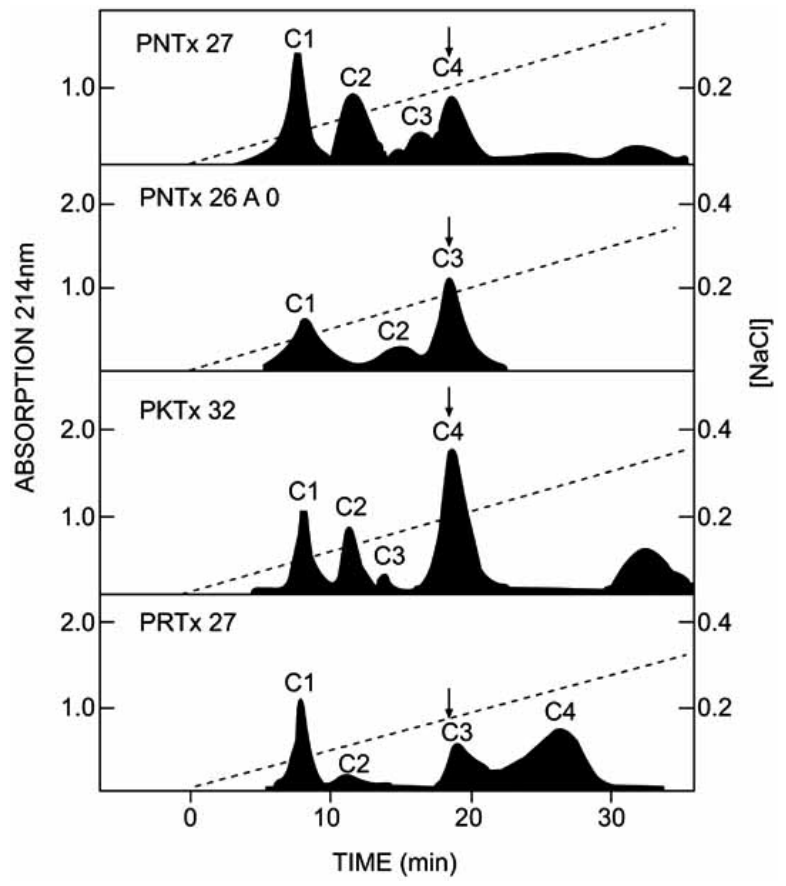

Figure 2. Profiles of the cation exchange FPLC chromatograpy. Cation exchange FPLC chromatography of the fractions PN27, PN26A0, PK32 and PR27 obtained from the preparative reversedphase HPLC. In the case of PN26A0, the fraction PN26 was subjected to an additional step of anion exchange FPLC on Synchropak AX-300 before being applied to the cation exchanger. The fractions were dissolved in $2 \mathrm{ml}$ of $10 \mathrm{mM}$ Na phosphate buffer $\mathrm{pH} 6.1$ and applied to a column of Resource $\mathrm{S}$ equilibrated in the same buffer. After washing with the starting buffer for 10min the column was then eluted with a gradient of $0-0.5 \mathrm{M} \mathrm{NaCl}$ in the same buffer at a flow rate of $1 \mathrm{ml} / \mathrm{min}$ over a period of $45 \mathrm{~min}$. The dotted line indicates the gradient concentration of $\mathrm{NaCl}$. The arrows indicate the peaks which were selected for desalting/further purification by reversed-phase HPLC on analytical columns of Vydac C18.

The proteins in each of the fractions PN27, PR27 and PK32 were then subjected to ion exchange FPLC on Resource $\mathrm{S}$ at $\mathrm{pH} 6.1$, using a gradient of $0-0.5 \mathrm{M} \mathrm{NaCl}$, which gave a good resolution of the mixtures, as depicted in Fig. (2). The small $4 \mathrm{kDa}$ proteins of interest were located in the peaks PN27C4, PR27C3 and PK32C4, all of which were eluted from the ion exchanger at a concentration of $0.2 \mathrm{M}$ $\mathrm{NaCl}$. A slightly different procedure was used for the material in PN26 which was initially fractionated on an anion exchange HPLC column of Synchropak AX-300 at pH 8.6, and eluted with a gradient of $0-0.5 \mathrm{M} \mathrm{NaCl}$. The majority of the protein in the mixture failed to bind to the column and was collected in the first peak PN26A0. The contents of this fraction were desalted, lyophilized and applied to FPLC on the Resource $\mathrm{S}$ cation exchanger at $\mathrm{pH}$ 6.1. This step yielded three peaks, the third of which, PN26A0C3, contained the 4 $\mathrm{kDa}$ protein. Each of the four fractions PN26A0C3, PN27C4, PR27C3 and PK32C4 obtained from the ion exchange chromatographies were then desalted and further purified by reversed-phase FPLC on an analytical column of Vydac18. 
All four fractions gave a single sharp band when examined by propionic acid/urea PAGE (not shown). The homogeneity of the proteins in the fractions PN26A0C3, PR27C3 and PK32C4 was confirmed by the results of Q-TOF mass spectroscopy, which indicated that their respective molecular masses were $4058.07 \pm 0.45,4043.64 \pm 0.22$ and $3996.78 \pm$ 0.03 . In the case of PN27C4, two molecular mass values of $4057.34 \pm 0.25$ and $4023.45 \pm 0.14$ were obtained, which suggested the presence of two very similar isoforms, and this was subsequently confirmed by amino acid sequencing which revealed the presence of phenylalanine and leucine in the cycle corresponding to position 7 .

The amino acid sequences of these toxins, determined by automated sequencing of the intact native proteins, the Spyridyl-ethylated forms, were confirmed by sequencing the peptides derived from them by digestion with trypsin. The sequences, shown in Fig. (3), are consistent with the measured molecular masses, which indicate that all 6 cysteines of each peptide form disulphide bridges. Inspection of the alignment of the sequences of these proteins reveals that they have between $67 \%$ and $92 \%$ sequence identity with one another, and $30-38 \%$ identity with toxins from other spiders such as huwentoxin-9 from the Chinese bird spider (Selenocosmia huwena) [32], hanatoxin-1 and hanatoxin-2 from the Chilean rose tarantula (Grammostola spatulata) [33], covalitoxin II from the Singapore tarantula (Coremiocnemis validus) [34], and agelenin from Agelena opulenta [35]. Interestingly this new family also has up to $52 \%$ sequence similarity with $\mathrm{ADO} 1, \mathrm{a} \mathrm{Ca}^{2+}$ channel toxin from the assassin bug Agriosphodrus dohrni [36]. All of these proteins caused spastic paralysis, followed by death in 40-60 min, when they were injected icv in mice at a single dose of $3.0 \mu \mathrm{g} / \mathrm{mouse}$, and conform to the Principal Structural Motif described for spider toxins [37].

Although other proteins of Phoneutria venom also produce spastic paralysis [5], the toxins reported in the present paper are not related to them. The alignment between the primary sequences on Fig. (3) shows that there is a significant identity between the assassin bug peptide and the toxins studied in this present work. Due to the scarce yield of our material, preliminary electrophysiological assays were carried out on L-type $\mathrm{Ca}^{2+}$ channels of GH3 cells. These channels have important physiological role in the control of blood pressure, heart beating, endocrine secretion, and modulation of neurotransmitter release. Fast inactivating LVA and noninactivating $\mathrm{HVA} \mathrm{Ba}^{2+}$ currents, which permeate through $\mathrm{Ca}^{2+}$ channels, have been reported in GH3 cells [38]. Although $\mathrm{Ca}_{\mathrm{v}} 2.1$ (P/Q-type) encoding mRNA has been detected, nearly all HVA currents are carried through dihydropyridine-sensitive L-type channels [17, 39]. GH3 cells also express $\mathrm{Na}^{+}$and $\mathrm{K}^{+}$channels $[14,40]$. In contrast with what could be expected from the mice symptoms, there was no significant effect of these neurotoxins on either $\mathrm{Na}^{+}$or $\mathrm{K}^{+}$ currents of these cells (not shown).

Fig. (4) shows the effect of PRTx27C3 (200 nM and 1 $\mu \mathrm{M})$ on $\mathrm{Ba}^{2+}$ currents. In the presence of PRTx27C3 (200 $\mathrm{nM}$ ) the non-inactivating currents were inhibited by $18 \%$ and there was a significant decrease $(50 \%)$ of the noninactivating currents, followed by a partial recovery, when the final concentration was $1 \mu \mathrm{M}$. Fig. (4A) and Fig. (4B) show the time-course of the toxin effect at $200 \mathrm{nM}$ and $1 \mu \mathrm{M}$ concentrations, respectively $(n=3)$. The maximal inhibition was observed about $20 \mathrm{~s}$ after the addition, and the effect was not reversed upon washing. The rate of inhibition by the toxin was not affected by the frequency of stimulation (not shown).

In the presence of PNTx27C4 $(1 \mu \mathrm{M}) \mathrm{Ba}^{2+}$ currents were inhibited by $16 \%$. Fig. (4C) shows the time-course of PNTx27C4 effect $(n=3)$. Similar to PRTx27C3, the maximal effect of PNTx27C4 was reached few seconds after the addition, and no immediate washout was observed. Fig. (4D) shows that in the presence of PNTx26An0C3 $(1 \mu \mathrm{M})$ there
A

PKTX32C4
PRTX27C3
PNTX27C4
PNTX26AN0C3

B

Agelenin
Huwentoxin-9
PRTX27C3
ADO1
Covalitoxin-2
Hanatoxin-1
Hanatoxin_2
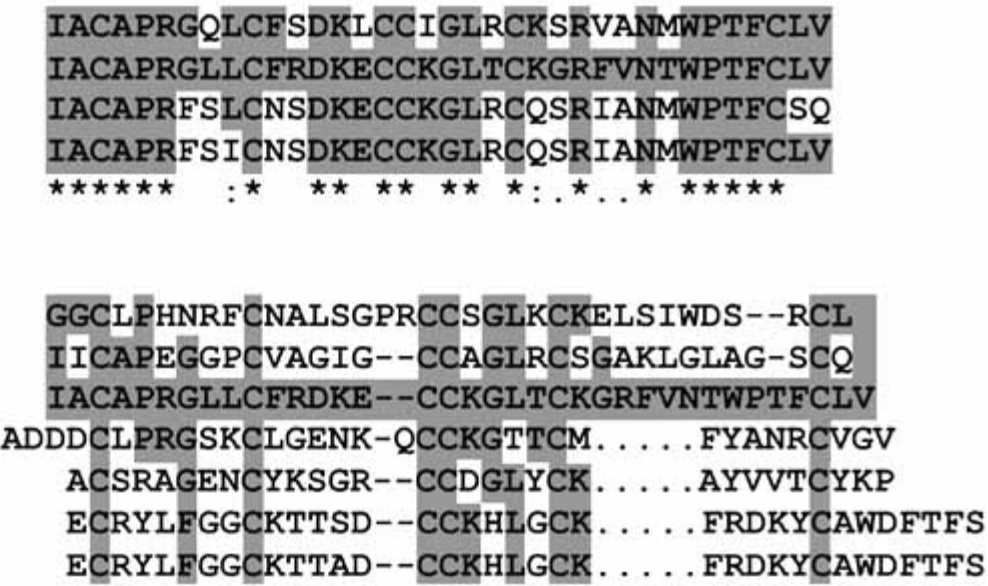

Figure 3. Sequence comparison with similar toxins. (A) Comparison of the amino acid sequences of the new 4kDa proteins (PNTx27C4, PNTx26A0C3, PRTx27C3 and PKTx32C4) isolated from the venoms of spiders of the genus Phoneutria. (B) Comparison of PRTx27C3 with huwentoxin 9 from the Chinese bird spider Selenocosmia huwena [32], hanatoxin-1 and hanatoxin-2 from the Chilean rose tarantula Grammostola spatulata [33], covalitoxin 2 from the Singapore tarantula Coremiocnemis validus [34], agelenin from Agelena opulenta [35] and ADO1 from the assassin bug Agriosphodrus dohrni [36]. The comparisons were carried out using CLUSTALW. In (B), dots were manually inserted to align the $6^{\text {th }}$ cysteine residue. The shaded residues are equal to the corresponding amino acid in PRTx27C3. 

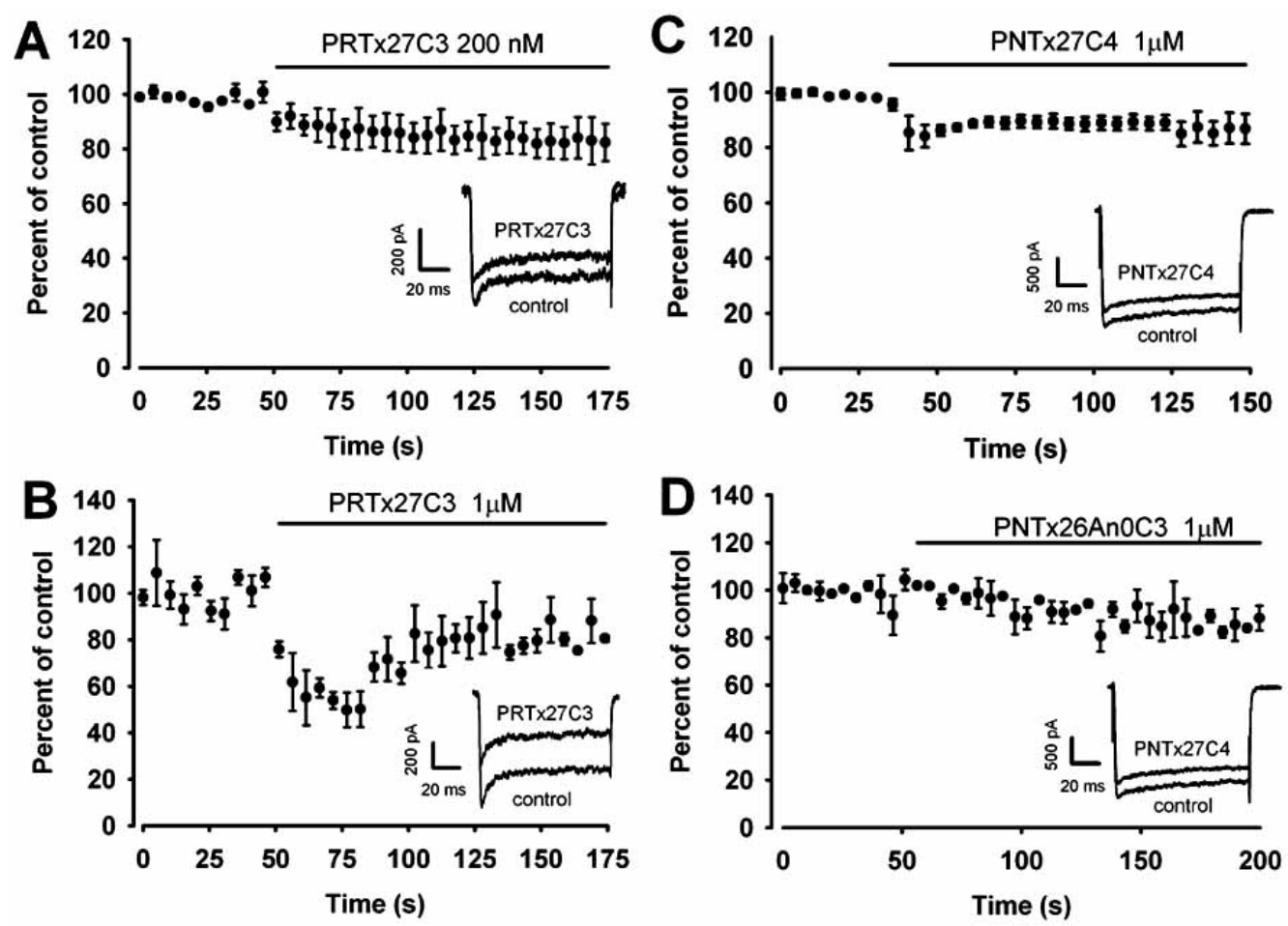

Figure 4. Effects of the purified toxins on L-type $\mathrm{Ba}^{2+}$ currents. (A) Time course of the effect of PRTx27C3 (200nM) in the steady-state Ltype $\mathrm{Ba}^{2+}$ currents (mean $\pm \mathrm{SEM}, n=3$ ) recorded at $0 \mathrm{mV}$. (B) Same as (A), but with $1 \mu \mathrm{M}$ of PRTx27C3.(C) Time course of the effect of PNTx27C4 $(1 \mu \mathrm{M})$ in the steady-state L-type $\mathrm{Ba}^{2+}$ currents (mean $\pm \mathrm{SEM}, n=3$ ) recorded at $0 \mathrm{mV}$. (D) Time course of the effect of PNTx26A0C3 $(1 \mu \mathrm{M})$ in the steady-state L-type $\mathrm{Ba}^{2+}$ currents (mean $\pm \mathrm{SEM}, n=3$ ) recorded at $0 \mathrm{mV}$. In all graphs the solid line shows the time interval for which the toxin was applied and the inserts show representative traces recorded at $0 \mathrm{mV}$ in the absence and in the presence of the toxin under investigation.

was a slow and small inhibition $(15 \%)$ of the $\mathrm{Ba}^{2+}$ current $(n=3)$, and no immediate washout was observed. Finally, $\mathrm{Ba}^{2+}$ currents were not significantly modified in the presence of PKTx32C4 (not shown).

Of the toxins with significant degree of identity with PRTx27C3, only two had their structures resolved so far: ADO1 [41] and Agelenin [42], PDB codes 1LMR and 2E2S, respectively. They display common features: both have compact core structures stabilized with three disulphide bridges, four loops and a short two stranded antiparallel $\beta$ sheet near the $\mathrm{C}$-terminal. Both belong to the inhibitory cysteine knot (ICK) structural family. Albeit agelenin is derived from a spider, it has characteristics that make it less suitable for our modeling: (i) contrary to ADO1, it is not active in mammalian $\mathrm{Ca}^{2+}$ channels in its native form [42], (ii) its sequence contains less identical residues than ADO1, as shown in Fig. (3), (iii) the amino acid residues reported to be important for agelenin activity are predominantly absent from PRTx27C3 [42]. Therefore, we used the structure of ADO1 as the initial template for modeling PRTx27C3, as described under Material and Methods. The modeled structure is depicted in Fig. (5). The Ramachandran plot statistics of this model, not considering the glycine residues, showed $61 \%$ of the dihedral angles laying in the most favorable regions, and 39\% in the additional favorable regions. No residue was found in the disallowed region (not shown). Bernard et al. [41], by comparing the thee-dimensional structure of
ADO1 with already known structures of other $\mathrm{Ca}^{2+}$ channels toxins, have observed conserved positioning of the amino acid residues R8, K11, K17, R31 and F27/Y28, and suggested that they might be significant for ADO1 activity. Fig. (3) shows that, of these proposed amino acids, R8 is well conserved in equivalent positions in the present family of peptides. The automatic superimposition of the model of PRTx27C3 and ADO1 structure, using Swiss-Pdb Viewer fitting routine, reveals close proximity of large stretches of the toxin backbones, mainly on the intermediate loop of ADO1, as shown in Fig. (5). This is the most conserved region of these molecules, as shown in Fig. (3). Interestingly, this structural alignment shows that three of the residues considered important for ADO1 activity, namely R8, K17 and F27, closely superimpose with the amino acid residues R6, K14 and F26 of PRTx27C3, respectively. Moreover, R6 and $\mathrm{K} 14$ are conserved in all toxins described in the present work. F26 is present only in PRTx27C3, and is replaced by less bulky hydrophobic residues in the other toxins, which have lower affinities. These amino acid residues are shown in Fig. (5), where they are displayed as sticks. One feature called our attention: Lys 21 of ADO1 and Lys18 of PRTx27C3 protrude from the molecule at the same position. This residue is also present in PNTx27C4 and PNTx26An0C3, but is absent from PKTx32C4, which is devoid of the inhibitory activity on L-type $\mathrm{Ba}^{2+}$ currents. There is some controversy on the effects of ADO1. Whilst it 

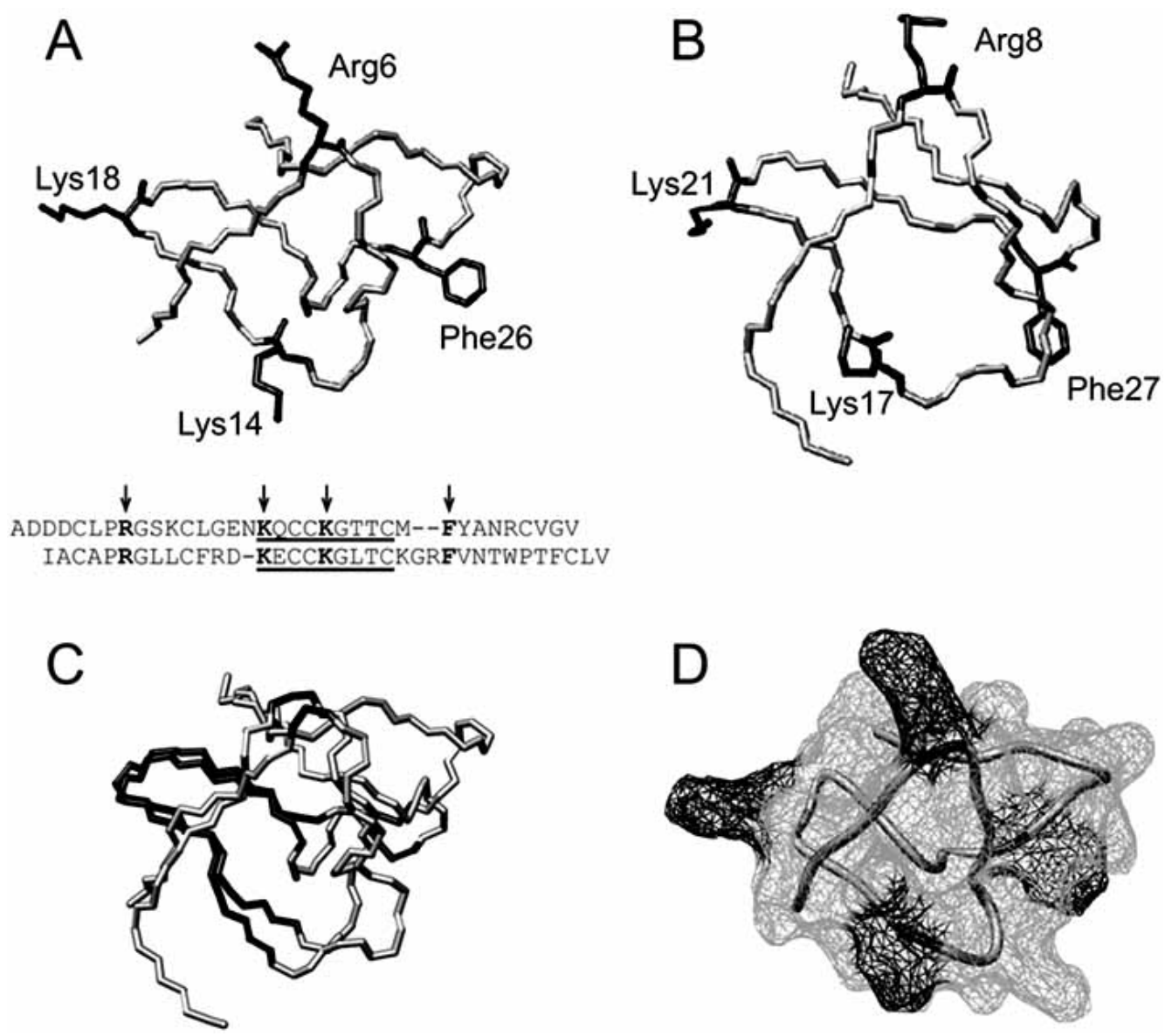

Figure 5. Proposed molecular model of PRTx27C3 - (A) model proposed for PRTx27C3; (B) the structure of ADO1 with the same orientation of the proposed model; (C) the two previous structures are superimposed, and the structural alignment is shown on top - the underlined sequences correspond to the black stretches of the structures. Only the backbone of all structures is shown, except for R6, K14, K18 and F26 in (A) and R8, K17, K21 and F27 in (B), whose side chains are displayed, and are assigned with arrows in the sequences in the top of (C); (D) The surface of the model of PRTx2C3 is shown, having its backbone displayed as a ribbon. The darker areas refer to the amino acid residues assigned with arrows. The orientation of the molecule is the same as in (A).

is reported as an L-type $\mathrm{Ca}^{2+}$ channel inhibitor on the PDB data bank, it is assumed in the literature as having no significant effect on L-type $\mathrm{Ca}^{2+}$ currents for its similarity with Ptu1 toxin, which is devoid of this effect. However, to our knowledge, while effect on P/Q-type mammalian $\mathrm{Ca}^{2+}$ channels has been shown, no direct determination of the effect of ADO1 on L-type channels has been reported in the literature. On the other hand, we cannot exclude the possibility that the toxins described in the present work have more prominent effect on other types of $\mathrm{Ca}^{2+}$ channels. The limited amount of pure material prevented us from testing this possibility.

Lysine residues have been shown to be crucial for inhibition $\mathrm{K}^{+}$and $\mathrm{Ca}^{2+}$ channels in other toxins. Furthermore, the motif $-\mathrm{C}-\mathrm{C}-\mathrm{K}$ - seen in these toxins is also present in other 13 toxins, including the L-type calcium channel blockers calciceptin and FS2, toxins from the black mamba snake. Some of these toxins act on other ion channels, notably $\mathrm{K}^{+}$channels. It has been pointed out the presence of conserved amino acid residues on $\mathrm{Ca}^{2+}$ and $\mathrm{K}^{+}$channels, which explained the similar effects of gramotoxin and hanatoxin, respectively, on these channels [43]. As seen in both our model of
PRTx27C3 and in the structure of ADO1, this motif places the lysine residue in a fixed position, whereas its side chain is very exposed and with high flexibility. Interestingly, a similar sequence (-C-C-R-) exists in $\omega$-conotoxin GVIA. Alanine substitution showed that the arginine residue of this sequence (Arg17) is important for the activity of the toxin, but not for its binding [44]. We suggest that the motif CCK is important for the activity of the present toxins.

It should be noted that there is some controversy over the exact taxonomic position of Phoneutria keyserlingi. Eickstedt [45] distinguished Phoneutria nigriventer from Phoneutria keyserlingi by the morphological characteristics of larger epigynal lateral guides and less curved embolus of the latter species. However Simo and Brescovit [46] consider that these differences only represent intraspecific variability, and suggest that Phoneutria keyserlingi should be regarded as a synonym of Phoneutria nigriventer. The results of this present biochemical investigation in which the amino acid sequences of three isoforms of proteins isolated from the venom of PN can be compared with single isoforms from PK 
and PR, show that whilst there are strong similarities between them, they are distinct molecules.

\section{ACKNOWLEDGEMENTS}

We thank Dr. Vera Regina von Eickstedt for the generous gift of spider venom, and Mr. Dario J. Souza for skillful technical assistance in animal bioassays. We are most grateful for financial support from: $\mathrm{CNPq}$ (Conselho Nacional de Desenvolvimento Científico e Tecnológico), MCT/CT-Infra, Instituto do Milênio de Nanociência - MCT, PRODOC/ CAPES, FUNED and FAPEMIG (Fundação de Amparo a Pesquisa do Estado de Minas Gerais, Edital 24000/01).

\section{ABBREVIATIONS}

ATP $=$ Adenosine 5'-triphosphate

cDNA $=$ Complementary DNA

DMEM = Dulbecco's modified Eagle's medium

EDTA $=$ Ethylenediaminetetraacetic acid

EGTA $=[$ Ethylene bis-(oxyethylenenitrilo $)]$ tetraacetic acid

FPLC = Fast Protein Liquid Chromatography

HEPES = (4-(2-hydroxyethyl)-1-piperazineethanesulfonic acid)

HPLC = High performance liquid chromatography

icv $=$ Intracerebroventricular

PAGE = Polyacrylamide gel electrophoresis

$\mathrm{PK}=$ Phoneutria keyserling $i$

$\mathrm{PN}=$ Phoneutria nigriventer

$\mathrm{PR} \quad=$ Phoneutria reidyi

SEM = Standard error of the mean

SPC = Simple Point Charge

TFA $=$ Trifluoroacetic acid

TEMED = N, N, N', N'-tetramethylethylenediamine

Tris $=$ Tris(hydroxymethyl)aminomethane

UV = Ultra violet

\section{REFERENCES}

[1] Mouhat, S., Jouirou, B., Mosbah, A., de Waard, M. and Sabatier, J.-M. (2004) Biochem. J., 378, 717.

[2] Escoubas, P., Diochot, S. and Corzo, G. (2000) Biochimie, 82, 893.

[3] Gomez, M.V., Kalapothakis, E., Guatimosim, C., and Prado, M.A.M. (2002) Cell. Molec. Neurobiol., 22, 579.

[4] Rash, L.D. and Hodgson, W.C. (2002) Toxicon, 40, 225

[5] Cordeiro, M.N., Richardson, M., Gilroy, J., Figueiredo, S.G., Beirão, P.S.L. and Diniz, C.R. (1995) J. Toxicol. Toxin Rev., 14, 309.

[6] Diniz, C.R., Cordeiro, M.N., Rezende Jr., L., Kelly, P., Fischer, S., Reimann, F., Oliveira, E.B. and Richardson, M. (1990) FEBS Lett., 263, 251.

[7] Rezende Jr., L., Cordeiro, M.N., Oliveira, E.B. and Diniz, C.R. (1991) Toxicon, 29, 1225.

[8] Cordeiro, M.N., Diniz, C.R., Valentim, A.C., von Eickstedt, V.R.D., Gilroy, J. and Richardson, M. (1992) FEBS Lett., 310, 153.
Cordeiro, M.N., Figueiredo, S.G., Valentim, A.C., Diniz, C.R., von Eickstedt, V.R.D., Gilroy, J. and Richardson, M. (1993) Toxicon, 31,35 .

[10] Figueiredo, S.G., Lima-Perez Garcia, M.E., Valentim, A.C., Cordeiro, M.N., Diniz, C.R. and Richardson, M. (1995) Toxicon, 33 83.

[11] Martin-Moutot, N., Mansuelle, P., Alcaraz, G., Santos, R. G., Cordeiro, M. N., Lima, M. E., Seagar, M. and Renterghem, C. V. (2006) Mol. Pharmacol., 69, 1931.

[12] Araújo, D.A.M., Cordeiro, M.N., Diniz, C.R. and Beirão, P.S.L. (1993) Naunyn-Schmiedebergs Arch. Pharmacol., 347, 205.

[13] Matavel, A., Cruz, J.S., Penaforte, C.L., Araújo, D.A.M., Kalapothakis, E., Prado, V.F., Diniz, C.R., Cordeiro, M.N. and Beirão, P.S.L. (2002) FEBS Lett., 523, 219.

[14] Kushmerick, C., Kalapothakis, E., Beirão, P.S.L., Penaforte, C.L., Prado, V.F., Cruz, J.S., Diniz, C.R., Cordeiro, M.N., Gomez, M.V. Romano-Silva, M.A. and Prado, M.A.M. (1999) J. Neurochem., 72, 1472.

[15] Prado, M.A.M., Guatimosin, C., Gomez, M.V., Diniz, C.R., Cordeiro, M.N. and Romano-Silva, M.A. (1996) Biochem. J., 314, 145 Guatimosim, C., Romano-Silva, M.A., Cruz, J.S., Beirão, P.S.L. Kalapothakis, E., Moraes-Santos, T., Cordeiro, M.N., Diniz, C.R., Gomez, M.V. and Prado, M.A.M. (1997) Brit. J. Pharmacol., 122, 591.

[17] Leão, R.M., Cruz, J.S., Diniz, C.R., Cordeiro, M.N. and Beirão, P.S.L. (2000) Neuropharmacology, 39, 1756.

[18] Cassola, A.C., Jaffe, H., Falles, H.M., Afeche, S.C., Magnoli, F. and Cipola-Neto, J. (1998) Pflugers Arch., 436, 545.

[19] Santos, R.G.D., van Renterghem, C., Martin-Moutot, N., Mansuelle, P., Cordeiro, M.N., Diniz, C.R., Mori, Y., de Lima, M.E. and Seagar, M. (2002) J. Biol. Chem., 277, 13856.

[20] Vieira, L.B., Kushmerick, C., Hildebrand, M.E., Garcia, E., Stea, A., Cordeiro, M.N., Richardson, M., Gomez, M.V. and Snutch, T.P. (2005) J. Pharmacol. Exp. Ther., 314, 1370.

[21] Kalapothakis, E., Penaforte, C.L., Leão, R.M., Cruz, J.S., Prado, V.F., Cordeiro, M.N., Diniz, C.R., Romano-Silva, M.A., Prado, M.A.M., Gomez, M.V. and Beirão, P.S.L. (1998) Toxicon, 36, 1971.

[22] Penaforte, C.L., Prado, V.F., Prado, M.A.M., Romano-Silva, M.A., Guimarães, P.E.M., de Marco, L., Gomez, M.V. and Kalapothakis, E. (2000) Toxicon, 38, 1443.

[23] Diniz, M.R.V., Paine, M.J.L., Diniz, C.R., Theakston, R.D.G. and Crampton, J.M. (1993) J. Biol. Chem., 268, 15340.

[24] Kalapothakis, E., Penaforte, C.L., Beirão, P.S.L., Romano-Silva, M.A., Cruz, J.S., Prado, M.A.M., Guimarães, P.E., Gomez, M.V. and Prado, V.F. (1998) Toxicon, 36, 1843.

[25] Pimenta, A.M.C., Rates, B., Bloch Jr., C., Gomes, P.C., Santoro, M.M., de Lima, M.E., Richardson, M. and Cordeiro, M.N. (2005) Rapid Commun. Mass Spectrom., 19, 31.

[26] Chettibi, S. and Lawrence, A. (1989) Toxicon, 27, 781

[27] Henschen, A. (1986) in B. Wittmann-Liebold, J. Salnikow (A. Erdmann, Ed). pp.244-255. Springer-Verlag, Berlin.

[28] Berendsen, H.J.C., van der Spoel, D., van Drunen, R. (1995) Comp Phys. Comm., 91, 43.

[29] van Gunsteren, W.F., Billeter, S.R., Eising, A.A., Hünenberger, P.H., Krüger, P., Mark, A.E., Scott, W.R.P. and Tironi, I.G. (1996) Hochschulverlag AG an der ETH, Zürich.

[30] Berendsen, H.J.C., Postma, J.P.M., van Gunsteren, W.F. and Hermans, J. (1981) in B. Pullman (Ed.). pp. 331-342. Reidel Publishing Company, Dordrecht.

[31] Berendsen, H.J.C., Postma, J.P.M., DiNola, A. and Haak, J.R. (1984) J. Chem. Phys., 81, 3684

[32] Liang, S.P. (2004) Toxicon, 43, 575

[33] Swartz, K.J. and MacKinnon, R. (1995) Neuron, 15, 941.

[34] Balaji, R., Sasaki, T., Gopalakrishnakone, P., Sato, K., Kini, R. and Bay, B.H. (2000) FEBS Lett., 474, 208.

[35] Hagiwara, K.I., Sakai, T., Miwa, A., Kawai, N. and Nakajima, T. (1990) Biomed. Res., 11, 181.

[36] Corzo, G., Adachi-Akahane, S., Nagao, T., Kusui, Y. and Nakajima, T. (2001) FEBS Lett., 499, 256.

[37] Kozlov, S., Malyavka, A., McCutchen, B., Lu, A., Schepers, E., Herrmann, R. and Grishin, E. (2005) Proteins, 59, 131.

[38] Armstrong, C.M. and Matteson, D.R. (1985) Science, 227, 65

[39] Liévano, A., Bolden, A. and Horn, R. (1994) Am. J. Physiol., 267, C411. 
[40] Campos, F.V., Coronas, F.I.V. and Beirão, P.S.L. (2004) Brit. J. Pharmacol., 142, 1115.

[41] Bernard, C., Corzo, G., Adachi-Akahane, S., Faures, G., Kanemaru, K., Furukawa, Y., Nakajima, T. and Darbon, H. (2004) Proteins, 54, 195.

[42] Yamaji, N., Sugase, K., Nakajima, T., Miki, T., Wakamori, M., Mori, Y. and Iwashita, T. (2007) FEBS Lett., 581, 3789.

Received: February 27, 2008

Revised: April 02, 2008

Accepted: April 16, 2008
$[43]$

\section{$[45]$}

[46]
Li-Smerin, Y. and Swartz, K.J. (1998) Proc. Natl. Acad. Sci USA, 95, 8585.

Lew, M.J., Flinn, J.P., Pallaghy, P.K., Murphy, R., Whorlow, S.L., Wright, C.E., Norton, R.S. and Angus, J.A. (1997) J. Biol. Chem., 272, 12014.

Eickstedt, V.R.D. (1979) Mem. Inst. Butantan, 43, 95.

Simo, M. and Brescovit, A.D. (2001) Bull. Br. Arachnol. Soc., 12, 67. 